\title{
Long-term active surveillance of leprosy suspects -what are the likely returns?
}

\author{
J. M. PÖNNIGHAUS, ${ }^{*}$ P. E. M. FINE, $\dagger$ J. A. STERNE, $\dagger$ \\ S. B. LUCAS $\$$ \& A. C. MCDOUGALL§ \\ *Universitäts-Hautklinik 6650 Homburg/Saar, Germany; †London \\ School of Hygiene and Tropical Medicine, Keppel Street, London \\ WCIE 7HT, UK; $\ddagger$ University College \& Middlesex School of \\ Medicine, The Bland-Sutton Institute, The Middlesex Hospital, \\ London WIP 7PN; §Department of Dermatology, Headington, \\ Oxford $\mathrm{OX} 37 \mathrm{JH}$
}

\section{Accepted for publication 17 September 1992}

\begin{abstract}
Summary Data are presented from the Karonga District in Northern Malawi on the long-term follow up of 277 leprosy suspects who were not given antileprosy treatment or kept on active surveillance. Individuals who were started on antileprosy treatment within a year after leprosy was first suspected, usually on the basis of histopathology results, are excluded from this analysis, because their active surveillance would not usually cause an organizational or financial problem for leprosy control projects. After an average follow-up period of 4.5 years 35 of the 277 suspects included in the analysis $(13 \%)$ were diagnosed with what we consider to be 'unequivocal' leprosy, and 3 of the 35 had developed disabilities. In $211 / 277(76 \%)$ all signs of leprosy had disappeared completely.

Comparing clinical certainties at first and last examinations and comparing clinical with histopathological certainties at last examinations it is estimated that up to $50 \%$ of the 35 cases of unequivocal leprosy which 'arose' in this group were attributable to misdiagnosis at the 1 st or 2 nd examination rather than to genuine progression of the disease. This estimate is compatible with an overall sensitivity of $90 \%$ and an overall specificity of $95 \%$ at each examination. Leprosy suspects with 1 cardinal sign of leprosy, either a typical lesion without loss of sensation, or loss of sensation in an otherwise untypical lesion, should be considered a high-risk group in that approximately $25 \%$ of such suspects $(19 / 78)$ were later found with unequivocal leprosy. Policies towards such suspects should be formulated by leprosy control projects.
\end{abstract}

\section{Introduction}

In any leprosy control or research project some individuals self-report or are found who have clinical signs (skin lesions, possibly enlarged nerves, or areas of sensory loss) which might be due to leprosy but in whom the diagnosis can neither be confirmed nor discarded 
with the usual diagnostic procedures. ${ }^{1,2}$ Policies towards such leprosy suspects vary. In some projects such individuals may not be treated but are encouraged to return if they notice any change in their lesions, or if additional lesions appear. Other projects may have a policy of active surveillance. Yet others may give antileprosy treatment to such suspects (in contrast to the WHO recommendation that if there is even the slightest doubt, the patient should be kept under observation until further evidence confirms the diagnosis'. ${ }^{3}$ ) This latter approach continues a tradition dating from medieval days, "that doubtful cases be observed over time so that the disease could declare itself unequivocally. ${ }^{14}$ In general, policies towards suspects are not clearly defined and are rarely stated within evaluation reports or national manuals. ${ }^{5,6}$

In this paper we present long-term follow-up data, derived from total population surveys, for leprosy suspects who were not given any antileprosy treatment and who were not kept on active surveillance. Several questions are at issue.

First, what percentage of leprosy suspects are likely to develop 'unequivocal' leprosy years after the disease was first suspected? We use the term unequivocal to imply that definite histopathological and/or clear clinical evidence of leprosy was found, at which point it would appear to be unethical not to give antileprosy treatment.

Second, can high risk suspects be identified, whom it would be particularly rewarding to follow-up? In contrast to short-term surveillance, long-term surveillance is expensive, and organizationally difficult. Thus, a policy of active long-term surveillance needs to be focused and well justified.

Third, to what extent can the finding of unequivocal leprosy at repeat examinations be attributed to genuine progression from early disease and to what extent might it be attributable to imperfect sensitivity and specificity at the successive examinations, which in theory may be improved.

We anticipate that information on these questions will be of use to control projects when formulating policies towards leprosy suspects.

Comparable data have not been published before. Several researchers have discussed the follow-up of untreated patients and have described self-healing rates among them..$^{7-9}$ Browne reported that lesions in 2749 patients with untreated indeterminate or tuberculoid leprosy resolved spontaneously. ${ }^{7}$ Noordeen described an inactivation rate of $10.9 \%$ per year for tuberculoid leprosy patients - a large proportion were said to have minimal lesions. ${ }^{8}$ Sirumban et al. found a cumulative healing rate of $38 \cdot 8 \%(92 / 237)$ within 2 years. ${ }^{9}$ Interpretation of and comparison between these investigations is difficult on account of the vagueness of the case definitions in the published reports. It may be that at least some of the 'patients' followed up did not have leprosy at all and would better have been described as 'suspects' in the first place. ${ }^{10}$

\section{Methods}

Between 1979 and 1990 two total population house-to-house surveys were carried out in Karonga District (Northern Malawii) as part of a longitudinal epidemiological study and leprosy vaccine trial. ${ }^{11,12}$

The paramedical workers (Leprosy Control Assistants, LCAs) engaged in the surveys were trained to suspect paucibacillary leprosy if they found any of the following: a hypopigmented lesion with a healing centre, a hypopigmented macule with a 'different' 
Table 1. Clinical certainty grades of suspected leprosy lesions (in the absence of a positive slit skin smear result)

\begin{tabular}{|c|c|c|c|c|}
\hline Grade & Definition & $\begin{array}{l}\text { Cardinal } \\
\text { signs }\end{array}$ & Lesion & Anaesthesia \\
\hline 0 & Not leprosy & 0 & 0 & 0 \\
\hline 1 & Possible leprosy & 0 & $\begin{array}{l}\text { Untypical lesion for which } \\
\text { no other explanation can be } \\
\text { found }\end{array}$ & $\begin{array}{l}\text { No anaesthesia to light } \\
\text { touch }\end{array}$ \\
\hline $2-$ & $\begin{array}{l}\text { Leprosy to be considered } \\
\text { seriously }\end{array}$ & 0 & $\begin{array}{l}\text { Lesion of less than typical } \\
\text { appearance }\end{array}$ & No anaesthesia \\
\hline $2+$ & & 1 & Untypical lesion & $\begin{array}{l}\text { Definite anaesthesia to light } \\
\text { touch }\end{array}$ \\
\hline 3 & Leprosy most likely & 1 & Lesion of typical appearance & No anaesthesia \\
\hline $3-$ & & 1 & $\begin{array}{l}\text { Definitely enlarged nerve, no } \\
\text { skin lesion }\end{array}$ & No anaesthesia \\
\hline $3+$ & & 1 & $\begin{array}{l}\text { Lesion of less than typical } \\
\text { appearance }\end{array}$ & $\begin{array}{l}\text { Definite anaesthesia to light } \\
\text { touch }\end{array}$ \\
\hline 4 & Leprosy extremely likely & 2 & Lesion of typical appearance & $\begin{array}{l}\text { Definite anaesthesia to light } \\
\text { touch } \\
\text { or definitely enlarged nerve }\end{array}$ \\
\hline 5 & Leprosy certain & 3 & Lesion of typical appearance & $\begin{array}{l}\text { Definite anaesthesia to light } \\
\text { touch } \\
\text { and definitely enlarged nerve }\end{array}$ \\
\hline
\end{tabular}

skin texture, a more or less infiltrated hypopigmented plaque, any other unexplained skin lesion, a nerve which appeared to be larger than normal, or any unexplained ulcer or wasting of muscles. They were trained to suspect multibacillary leprosy if they found multiple macules, plaques or papules. Anaesthesia to light touch, diminished pain sensation and loss of thermosensation were sought, but the suspicion of leprosy did not require such additional evidence. All individuals found with any signs suggestive of leprosy were reviewed by a project medical officer (generally J.M.P.). If the Medical Officer (MO) agreed that leprosy was a possible explanation for the signs, he assigned a clinical certainty grade to the findings, unless he was already aware of a positive slit-skin smear. ${ }^{13}$ At the same time, provided the suspect agreed, a biopsy was obtained from the lesion(s). Usually one or several $4 \mathrm{~mm}$ punch biopsies were taken from skin lesion(s), and occasionally a split nerve biopsy was obtained from a nerve thought to be enlarged. When carrying out repeat examinations the LCAs or the MO were never aware of clinical certainty grades given at previous examinations.

The clinical certainty scale evolved gradually during the 10 years of the project (Table 1). Inevitably results of more than 2000 biopsies taken and reported during the decade influenced the MO's opinion of what constitutes a typical lesion. Despite such experience, the scale remains subjective, and the precise boundaries between 'untypical', 'less than typical' and 'typical' (= textbook-like) lesions will always remain a matter of personal judgement. It will be noted that only anaesthesia to light touch is formally taken into account in this certainty scale, as this test alone is carried out at every examination. Tests 
Table 2. Clinical and histopathological certainty grades in 1313 previously untreated leprosy suspects at first examination, Karonga District 1979-1990.* Row percentages in parentheses. Numbers of suspects who were started on antileprosy treatment within a year after leprosy was first suspected are given in bold italics.

\begin{tabular}{|c|c|c|c|c|c|c|c|c|}
\hline & & \multirow[b]{2}{*}{$\begin{array}{l}\text { Definite } \\
\text { anaesthetic } \\
\text { to light } \\
\text { touch }\end{array}$} & \multicolumn{5}{|c|}{ Histopathological certainty grade } & \multirow[b]{2}{*}{ Total } \\
\hline \multicolumn{2}{|c|}{$\begin{array}{l}\text { Clinical certainty } \\
\text { grade }\end{array}$} & & $\begin{array}{l}\text { Definite } \\
\text { evidence }\end{array}$ & $\begin{array}{c}\text { Probable } \\
\text { evidence } \\
>\text { October } \\
1985\end{array}$ & $\begin{aligned} & \text { Some } \\
& \text { evidence } \\
&<\text { October } \\
& 1985\end{aligned}$ & $\begin{array}{c}\text { Possible } \\
\text { evidence } \\
>\text { October } \\
1985\end{array}$ & $\begin{array}{c}\text { No } \\
\text { evidence }\end{array}$ & \\
\hline 1 & $\begin{array}{l}\text { Possible } \\
\text { leprosy }\end{array}$ & No & $\begin{array}{c}40 \\
(10 \cdot 2)^{*} \\
36\end{array}$ & $\begin{array}{c}11 \\
(2 \cdot 8) \\
1\end{array}$ & $\begin{array}{c}35 \\
(8 \cdot 9) \\
3\end{array}$ & $\begin{array}{c}68 \\
(17 \cdot 4) \\
0\end{array}$ & $\begin{array}{c}238 \\
(60 \cdot 7) \\
3\end{array}$ & $\begin{array}{r}392 \\
43\end{array}$ \\
\hline 2 & $\begin{array}{l}\text { Consider } \\
\text { seriously }\end{array}$ & No & $\begin{array}{c}115 \\
(30 \cdot 4) \\
114\end{array}$ & $\begin{array}{c}13 \\
(3 \cdot 4) \\
2\end{array}$ & $\begin{array}{c}27 \\
(7 \cdot 1) \\
0\end{array}$ & $\begin{array}{c}65 \\
(17 \cdot 2) \\
1\end{array}$ & $\begin{array}{c}158 \\
(41 \cdot 8) \\
0\end{array}$ & $\begin{array}{l}378 \\
117\end{array}$ \\
\hline $2+$ & & Yes & $\begin{array}{c}24 \\
(39 \cdot 3) \\
24\end{array}$ & $\begin{array}{c}6 \\
(9 \cdot 8) \\
2\end{array}$ & 0 & $\begin{array}{c}7 \\
(11 \cdot 5) \\
0\end{array}$ & $\begin{array}{c}24 \\
(39 \cdot 3) \\
1\end{array}$ & $\begin{array}{l}61 \\
27\end{array}$ \\
\hline $3-$ & Most likely & No & $\begin{array}{c}166 \\
(49 \cdot 7) \\
163\end{array}$ & $\begin{array}{c}4 \\
(1 \cdot 2) \\
2\end{array}$ & $\begin{array}{c}61 \\
(18 \cdot 3) \\
28\end{array}$ & $\begin{array}{c}18 \\
(5 \cdot 4) \\
5\end{array}$ & $\begin{array}{c}85 \\
(25 \cdot 5) \\
13\end{array}$ & $\begin{array}{l}334 \\
211\end{array}$ \\
\hline $3+$ & & Yes & $\begin{array}{c}79 \\
(53 \cdot 4) \\
77\end{array}$ & $\begin{array}{c}10 \\
(6 \cdot 8) \\
6\end{array}$ & $\begin{array}{c}3 \\
(2 \cdot 0) \\
3\end{array}$ & $\begin{array}{c}28 \\
(18 \cdot 9) \\
7\end{array}$ & $\begin{array}{c}28 \\
(18 \cdot 9) \\
3\end{array}$ & 148 \\
\hline Tot & & & $\begin{array}{l}424 \\
414\end{array}$ & $\begin{array}{l}44 \\
13\end{array}$ & $\begin{array}{r}126 \\
34\end{array}$ & $\begin{array}{r}186 \\
13\end{array}$ & $\begin{array}{r}533 \\
20\end{array}$ & $\begin{array}{r}1313 \\
494\end{array}$ \\
\hline
\end{tabular}

for diminished pain sensation are frequently impräcticable due to lack of understanding on the part of the patient or suspect, and the test for loss of thermosensation has only recently become a matter of routine. A comparison of results between these 3 sensory loss tests has been published. ${ }^{14}$

For the purpose of this paper we define leprosy suspects as individuals with clinical certainty grades $1-3$ at the first examination. Depending on whether definite anaesthesia to light touch was recorded as absent or present in the field, we have split certainty grades 2 and 3 into $2-$ and $2+$, and $3-$ and $3+$, respectively (Table 2 ). The first examination is the one at which leprosy was first suspected. Unequivocal leprosy is defined as definite histopathological evidence of leprosy and/or a clinical certainty grade of 4 or 5 . We use the phrase last examination to refer to the examination at which unequivocal leprosy was diagnosed or else the examination when the suspect was last seen without unequivocal leprosy. As the purpose of this paper is to investigate the usefulness of long-term surveillance of leprosy suspects, we have restricted the analysis to suspects whose last examination was more than 1 year after leprosy was first suspected. So, suspects are excluded from this analysis if they were started on antileprosy treatment within a year of the 1st examination either because of a histopathology result or at a further review examination prompted, e.g. by a histopathology result. This criterion implies a large increase in the sensitivity of the initial diagnostic evaluation (494/1313 suspects were registered within a year after leprosy was first suspected, as shown in Table 2) but 
probably only a marginal decrease in specificity. Histopathology results were examined critically by the project MOs, which explains why 10/424 with definite histopathological evidence of leprosy were not started on antileprosy treatment. In most of them the true diagnosis was secondary (granulomatous) syphilis, which may resemble very closely tuberculoid leprosy histologically.

Nearly all suspects discussed here ( $87 / 102$ for whom the mode of case finding has been coded) were found during the house-to-house surveys.

All leprosy suspects included in this analysis agreed to have biopsies taken. Until late 1985 the histopathologist (A.C.M.) was provided with basic information about the biopsied lesion; after that date all biopsies were examined 'blind' (by A.C.M. or S.L.), with no clinical information except the part of the body from which the biopsy was taken. The histopathologist always provided an indication of his confidence that the lesion was attributable to leprosy, using a certainty scale which we have described elsewhere. ${ }^{15,16}$ In short, criteria for definite leprosy in a skin biopsy are: a, endoneurial granuloma(s) disrupting nerve; and/or b, one or more genuine (noncontaminant) AFB in a nerve or granuloma in association with perineural inflammation. Initially, until October 1985, there was only one grade if histopathological findings were consistent with but not pathognomonic of leprosy, called: 'some evidence'. Later, after October 1985, two grades were used for this situation: 'suggestive of but not diagnostic of leprosy=probably leprosy' and 'possibly leprosy'.

A major problem in the interpretation of follow-up data such as those presented here is the distinction between true changes over time and apparent changes which are in fact attributable to misdiagnosis at initial or subsequent examination. In order to quantify this misdiagnosis effect, we explored the implications of different levels of sensitivity and specificity on expected results of follow-up examinations of individuals not considerred to have unequivocal leprosy at the first examination. Using the following symbols:

$\mathrm{TP}$, true prevalence rate of leprosy in the population;

$\mathrm{SN} 1, \mathrm{SN} 2$, sensitivity of diagnosis at the 1 st and subsequent examinations, respectively; SP1, SP2, specificity of diagnosis at the 1st and subsequent examinations, respectively; OP1, OP2, 'observed unequivocal' leprosy rates at the 1 st and subsequent examinations, respectively;

$\mathrm{RP} 1$, remaining true prevalence in those not considered positive at the 1st examination.

The following relationships hold:

$$
\begin{aligned}
& \mathrm{OP} 1=\mathrm{TP} \times \mathrm{SN} 1+(1-\mathrm{TP}) \times(1-\mathrm{SP} 1) \\
& \mathrm{RP} 1=\mathrm{TP} \times(1-\mathrm{SN} 1) /(1-\mathrm{OP} 1) \\
& \mathrm{OP} 2=\mathrm{RP} 1 \times \mathrm{SN} 2-(1-\mathrm{RP} 1) \times(1-\mathrm{SP} 2) .
\end{aligned}
$$

The proportion observed with unequivocal leprosy at a 2 nd examination (OP2) is thus equal to the remaining true prevalence of unequivocal leprosy among initially negative suspects (RP1) times the sensitivity at the repeat examination (SN2), corrected for the effects of imperfect specificity of the repeat examination.

\section{Results}

During the total population surveys a total of 1313 previously untreated leprosy suspects were found and biopsied. An additional 13 suspects refused to be biopsied. Table 2 gives a 
Table 3. Clinical certainty grades at the 1 st examination (rows) versus clinical certainty grades at the last examination (columns) of 277 suspects. Individuals with 'unequivocal leprosy' on clinical and/or histopathological grounds at last examination are shown in bold italics.

\begin{tabular}{|c|c|c|c|c|c|c|c|c|c|}
\hline \multirow{2}{*}{$\begin{array}{l}\text { Clinical } \\
\text { certainty } \\
\text { grade }\end{array}$} & \multicolumn{8}{|c|}{ Last examination } & \multirow[b]{2}{*}{ Tota } \\
\hline & 0 & 1 & $2-$ & $2+$ & $3-$ & $3+$ & 4 & 5 & \\
\hline \multirow[t]{2}{*}{1} & 95 & 2 & 4 & 4 & 3 & 1 & 4 & 2 & 115 \\
\hline & 0 & 1 & 1 & 1 & 1 & 0 & 4 & 2 & 10 \\
\hline \multirow[t]{2}{*}{$2-$} & 66 & 2 & 5 & 1 & 5 & 2 & 3 & 0 & 84 \\
\hline & 0 & 0 & 0 & 0 & 3 & 0 & 3 & 0 & 6 \\
\hline \multirow[t]{2}{*}{$2+$} & 2 & 0 & 0 & 0 & 0 & 0 & 1 & 0 & 3 \\
\hline & 0 & 0 & 0 & 0 & 0 & 0 & 1 & 0 & 1 \\
\hline \multirow[t]{2}{*}{$3-$} & 41 & 0 & 8 & 1 & 6 & 1 & 6 & 0 & 63 \\
\hline & 0 & 0 & 5 & 1 & 2 & 1 & 6 & 0 & 15 \\
\hline \multirow[t]{2}{*}{$3+$} & 7 & 0 & 1 & 0 & 0 & 2 & 1 & 1 & 12 \\
\hline & 0 & 0 & 0 & 0 & 0 & 1 & 1 & 1 & 3 \\
\hline \multirow[t]{2}{*}{ Total } & 211 & 4 & 18 & 6 & 14 & 6 & 15 & 3 & 277 \\
\hline & 0 & 1 & 6 & 2 & 6 & 2 & 15 & 3 & 35 \\
\hline
\end{tabular}

+ , with definite anaesthesia to light touch.

-, without definite anaesthesia to light touch.

cross-tabulation of the clinical and histopathological certainty grades at the $1 \mathrm{st}$ examination of these 1313 individuals. Table 2 shows that 494 of the 1313 were started on antileprosy treatment because of definite histopathological evidence (414) or because further clinical evidence came to light at a review examination within a year after leprosy was first suspected (80). Of the remaining suspects, 277 have so far been re-examined in the course of the house-to-house surveys more than a year after leprosy was first suspected, and are the subject of this paper.

A strong correlation between clinical and histopathological certainty gradings is evident in Table 2. Among suspects with one cardinal sign of leprosy (clinical certainty grades $2+, 3-, 3+$ ) definite histopathological evidence of leprosy was found in $(24+166+79) /(61+334+148)=49 \cdot 5 \%$ of the biopsy specimens taken. This may be compared to those in whom leprosy was considered to be only a 'possibility', in whom only $40 / 392(10 \cdot 2 \%)$ of biopsy specimens offered definite evidence of leprosy. In 115/378 $(30.4 \%)$ of thosewith a clinical certainty grade $2-$ (lesions of less than typical appearance and without anaesthesia to light touch) the histopathologist found definite evidence of leprosy.

Table 3 provides a cross-tabulation of clinical certainties at the 1 st and the last examinations. All signs of leprosy had disappeared (=clinical certainty zero at last examination) in $211 / 277=76 \cdot 2 \%$. The average follow-up period was $4 \cdot 8$ years for those in whom no signs of leprosy were found any more, 4.0 years for 31 individuals whose lesions, still unconfirmed as leprosy, persisted at the last examination and $4 \cdot 1$ years for the remaining 35 individuals whose lesions persisted and who were ultimately confirmed as having unequivocal leprosy. A comparison of the 1 st and the last examinations of these 35 
Table 4. Clinical and histopathological certainty grades in 80 individuals who were considered still to have signs of leprosy and who were biopsied more than a year after an initial examination at which leprosy had first been suspected. Individuals considered to have unequivocal leprosy on either histopathological or clinical grounds are shown in bold italics.

\begin{tabular}{lcccccc}
\hline \multicolumn{5}{c}{ Histopathological certainty grade } \\
$\begin{array}{lccccc}\text { Clinical } \\
\text { certainty } \\
\text { grade }\end{array}$ & $\begin{array}{l}\text { Definite } \\
\text { evidence }\end{array}$ & $\begin{array}{c}\text { Probably } \\
\text { leprosy }\end{array}$ & $\begin{array}{c}\text { Some } \\
\text { evidence }\end{array}$ & $\begin{array}{c}\text { Possibly } \\
\text { leprosy }\end{array}$ & No evidence & Total \\
\hline 1 & $\mathbf{1}$ & 1 & 0 & 3 & 1 & 6 \\
2 & $\mathbf{8}$ & 1 & 0 & 3 & 13 & 25 \\
3 & $\mathbf{8}$ & 1 & 0 & 9 & 13 & 31 \\
4 & $\mathbf{1 0}$ & 0 & 0 & 0 & 5 & 15 \\
5 & $\mathbf{3}$ & 0 & 0 & 0 & 0 & 3 \\
Total & $\mathbf{3 0}$ & 3 & 0 & 15 & 32 & 80 \\
\hline
\end{tabular}

Table 5. Eventual outcome for 277 leprosy suspects who were reviewed more than a year after leprosy was first suspected, in relation to initial clinical certainty, Karonga District 19791990.

\begin{tabular}{lccr}
\hline & Definite anesthesia \\
to light touch & $\begin{array}{c}\text { Number of suspects who } \\
\text { were subsequently found } \\
\text { with unequivocal leprosy }\end{array}$ & Total \\
\hline $1 \quad$ 'Possible leprosy' & No & $10^{*}(8 \cdot 7) \ddagger$ & 115 \\
$2-$ 'Leprosy to be & $6 \quad(7 \cdot 1)$ & 84 \\
$2+\quad$ considered seriously' & Yes & 1 & 3 \\
$3-$ 'Leprosy most likely' & No & $15(23 \cdot 8)$ & 63 \\
$3+\quad$ Yes & $3 \dagger(25 \cdot 0)$ & 12 \\
Total & & $35 \quad(12 \cdot 6)$ & 277 \\
\hline
\end{tabular}

* Two individuals or $\dagger$ one individual in each of these groups developed disabilities during the interval between two examinations.

$\ddagger$ Numbers on parentheses are percentages.

individuals (numbers in bold italics in Table 3), shows that clinical certainties had increased by at least 2 grades in $12 / 35(34 \cdot 3 \%)$, increased by 1 grade in $12 / 35(34 \cdot 3 \%)$, stayed the same in $5 / 35(14 \cdot 29 \%)$, and decreased by 1 grade in $6 / 35(17 \cdot 14 \%)$.

Repeat biopsies were obtained from 80 of the 277 leprosy suspects at one or another repeat examination (Table 4). Of these 80 individuals, 35 were considered to have unequivocal leprosy. As can be seen in Table 4, the strong evidence for unequivocal leprosy was both clinical (certainty grades 4 and 5) and histopathological (certainty grade 1) in $10+3=13(37 \cdot 1 \%)$; histopathological alone in $1+8+8=17(48 \cdot 6 \%)$; and clinical alone in $5(14 \cdot 3 \%)$. A total of 6 of the 35 with unequivocal leprosy is known to have self- 
Table 6. Eventual outcome for 277 leprosy suspects who were reviewed more than a year after leprosy was first suspected in relation to initial histopathological certainty, Karonga District 1979-1990.

\begin{tabular}{lcr}
\hline $\begin{array}{l}\text { Original } \\
\text { histopathological } \\
\text { certainty }\end{array}$ & $\begin{array}{c}\text { Number of suspects who } \\
\text { were later found } \\
\text { with unequivocal leprosy }\end{array}$ & Total \\
\hline $\begin{array}{l}\text { Probable leprosy }>\text { October 1985 } \\
\text { Some evidence }<\text { October 1985 }\end{array}$ & 0 & 1 \\
possible leprosy $>$ October 1985 & $17(22 \cdot 7) \dagger$ & 75 \\
no evidence & $6(27 \cdot 3)$ & 22 \\
Total & $12 *(6 \cdot 7)$ & 179 \\
\hline
\end{tabular}

\footnotetext{
* In this group 3 individuals developed disabilities during the interval between 2 examinations.

$\dagger$ Numbers in parentheses are percentages.
}

Table 7. Expected observed proportion positive at a 2 nd screening procedure as a function of true original prevalence rates and different sensitivities and specificities of the screening procedures. In this context we consider the combined clinical and histopathological examinations to be the screening procedure.

\begin{tabular}{|c|c|c|c|c|}
\hline \multirow{2}{*}{$\begin{array}{l}\text { Sensitivity } \\
\text { of } 1 \text { st and } \\
\text { 2nd screen }\end{array}$} & \multirow{2}{*}{$\begin{array}{l}\text { Specificity } \\
\text { of } 1 \text { st and } \\
\text { 2nd screen }\end{array}$} & \multicolumn{3}{|c|}{ True original prevalence rate } \\
\hline & & $0 \cdot 1$ & $0 \cdot 3$ & $0 \cdot 5$ \\
\hline & & \multicolumn{3}{|c|}{$\begin{array}{l}\text { Proportion positive expected at } \\
2 \text { nd screening (in the absence of } \\
\text { self-healing and progression) }\end{array}$} \\
\hline $0 \cdot 9$ & $0 \cdot 98$ & $0 \cdot 030$ & $0 \cdot 057$ & $0 \cdot 101$ \\
\hline 0.95 & 0.98 & 0.025 & $0 \cdot 040$ & $0 \cdot 065$ \\
\hline $0 \cdot 9$ & 0.95 & $0 \cdot 060$ & $0 \cdot 087$ & $0 \cdot 131$ \\
\hline 0.95 & 0.95 & $0 \cdot 055$ & $0 \cdot 070$ & 0.095 \\
\hline
\end{tabular}

reported to LCAs while 28 were found during the house-to-house surveys. For 1 patient the mode of detection was not recorded.

Table 5 shows the numbers and percentages of suspects later found with unequivocal leprosy by clinical certainty at the 1 st examination-3 of the suspects had developed disabilities by the time they were seen again, 2 of whom had a clinical certainty of only 1 ('possibly leprosy') when leprosy was first suspected. Nearly a quarter (19/78) of those originally found with 1 cardinal sign of leprosy have developed unequivocal leprosy so far. The percentages of suspects who developed unequivocal leprosy were similar for males and females and did not vary significantly by age (not shown).

Table 6 provides a breakdown of numbers and percentages which developed unequivocal leprosy by original histopathological certainty. Only $6 \cdot 7 \%$ (12/179) of those in whom the histopathologist did not find any evidence of leprosy in the first specimen(s) 
were later found with unequivocal leprosy, compared to $23 \cdot 5 \%(17+6 / 1+75+22)$ for those in whom some histopathological evidence was found in the initial biopsy. However, 3 of the 12 with no initial histopathological evidence of leprosy developed disabilities during the interval between 2 examinations.

Table 7 shows the implications of various levels of sensitivity and specificity on the percentage expected to be found with unequivocal leprosy at a repeat examination ( = '2nd screening'). If we assume that the original true prevalence rates among those with clinical certainty grades 1 ('possibly leprosy'), 2 ('leprosy to be considered seriously') and 3 ('leprosy most likely') were $0 \cdot 1,0 \cdot 3$ and $0 \cdot 5$, respectively, and that the sensitivity and specificity were 0.9 and 0.95 , respectively, we would expect to observe between 6 and $13 \%$ of individuals as having 'unequivocal leprosy' on the 2 nd examination as an effect of misdiagnosis at the 1 st and 2 nd examinations. If the sensitivity and specificity were higher, $95 \%$ and $98 \%$ respectively, we would expect to find 'unequivocal leprosy' at the 2nd examination attributable to misdiagnosis in only $2 \cdot 5 \%, 4 \cdot 0 \%$ and $6 \cdot 5 \%$ of suspects, with original clinical certainty grades of 1,2 and 3 , respectively.

\section{Discussion}

This paper reports the follow-up results of 277 individuals who were identified initially as leprosy suspects, but to whom no antileprosy treatment was given on account of insufficient evidence to support the diagnosis. After an average of 4.5 years, $35(12 \cdot 6 \%)$ were considered to have unequivocal leprosy, whereas $211(76 \cdot 2 \%)$ had lost all signs of the disease. The probability of unequivocal leprosy eventually emerging was a function of the clinical and histopathological certainty at the 1 st examination. Nearly a quarter of those with 1 cardinal sign of leprosy (clinical certainty of $2+, 3-$ or $3+$ ) or some histopathological evidence of leprosy at the 1 st examination were later thought to have unequivocal leprosy. These findings identify such suspects as a high-risk group which a control project may consider worthy of active long-term surveillance. On the other hand, only 1 of the 3 suspects who developed disabilities during the interval between 2 examinations was in the clinical high-risk group. The risk factor 'some histopathological evidence of leprosy' is of course less useful for most control projects which do not have histopathology services.

It should be recognized that the figures concerning the development of unequivocal leprosy are a function of our definition of a suspect. If a wider definition of leprosy had been used such as that "eliciting impairment in sensibility in a suggestive skin lesion . . clinches the diagnosis leprosy', ${ }^{17}$ up to $(3+63+12) / 277=28 \%$ (see Table 3 ) of the suspects in this investigation would have been considered to have leprosy at the $1 \mathrm{st}$ examination, and the percentage of suspects found eventually with unequivocal leprosy would probably have been lower than reported here (given that lesions disappeared completely from more than three-quarters of the suspects).

Given that there is no 'gold standard' for the diagnosis of clinical leprosy, in particular of 'early' leprosy, no self-healing rates of early leprosy can confidently be derived from this series of suspects. If it were assumed that all the suspects had early leprosy the percentage which had self-healed by the time they were last seen would be $76 \cdot 2 \%(211 /$ 277). However, such an assumption is extreme and we would not like to make it. 
For the purposes of control projects the issue of whether a later finding of unequivocal leprosy is due to progression of disease or to misdiagnosis at one examination or other is important. Sensitivity and specificity may in theory be improved, whereas progression rates are presumably inherent in the disease process.

We have therefore investigated to what extent the finding of unequivocal leprosy at later examinations might be due to the effects of misdiagnosis, that is, imperfect sensitivity and specificity, at the examinations. It may be argued that at least in those $(5+6) / 35$ $(31.4 \%)$ in whom the clinical certainty had stayed the same or decreased (see Table 3 ), the finding of definite histopathological evidence at the last examination was a result of misdiagnosis - of either a false-negative misdiagnosis at the 1st or a false-positive misdiagnosis at the 2 nd examination. In addition it can be suspected that in some of those $5 / 35(14.3 \%)$ in whom the clinical certainty of 4 (extremely likely) at the last examination was not supported by histopathological findings the diagnosis of unequivocal leprosy was due to false-positive clinical misdiagnosis at the last examination. So, if up to half of all 'unequivocal leprosy' identified at the last examination were the result of such sensitivity and specificity problems this would be about $6 \%$ of the suspects, i.e. half of the $12.6 \%$ found with unequivocal leprosy at the last examination. It is interesting to note that a sensitivity of $90 \%$ combined with a specificity of $95 \%$ would be compatible with this figure (see Table 7) if the overall true prevalence rate among suspects were around $10 \%$. In the absence of additional data we do not wish to speculate further on the most likely sensitivity and specificity values in this investigation. There have been very few attempts to estimate these parameters in leprosy studies, though Gupte et al. estimated sensitivity rates of $74-91 \%$ and a specificity of $98 \%$ in a study carried out in South India. ${ }^{18}$

It is beyond the scope of this paper to discuss in detail the practicalities of following suspects over long periods of time rather than giving them antileprosy treatment. However, we would emphasize our principal finding that suspects with 1 cardinal sign of leprosy form a group of people which should receive considerable thought and attention in any project. A quarter of them are likely to manifest unequivocal leprosy as the years pass. Maybe, as a first step, the sensitivity and specificity of their examinations can be improved using histopathology and serology if practicable?

Few field workers will consider long-term active surveillance of leprosy suspects a feasible policy, as it is not only very difficult and time consuming but might, in some communities, cause unacceptable stigma. Intensive health education towards subsequent self-reporting directed at particular groups of suspects found to be at a high risk could be another possible approach.

\section{Acknowledgments}

The Lepra Evaluation Project-Karonga Prevention Trial is funded by LEPRA (The British Leprosy Relief Association), ILEP (The International Federation of AntiLeprosy Organizations) and IMMLEP (The Immunology of Leprosy component of the WHO/TDR). We express our sincere thanks to the leprosy control assistants engaged in the total population surveys, in particular Messrs B. Mwamondwe, E. Msosa, P. Mwafulirwa, D. Chavula, H. Phiri, A. Kasunga, M. Munthali, J. Nyierenda and Ms M. Nafukwe. 


\section{References}

I Jacob M, Mathai R. Diagnostic efficacy of cutaneous nerve biopsy in primary neuritic leprosy. Int J Lep, 1988; 56: 56-60.

2 Neelan PN, Noordeen SK, Ramu G, Desikan KV, Prabhu KPM, Christian M. Inter-observer variations in diagnosis and classification of early lesions of leprosy. Leprosy in India, 1982; 54: 485-488.

3 World Health Organization. A guide to leprosy control (2nd edition). WHO, Geneva, 1988.

4 Ell SR. Leprosy and social class in the middle ages. Int J Lepr, 1986; 54: 301-305.

5 Rangaraj M. Leprosy Control Programme Sierra Leone Evaluation Report 1973-1987.

6 Tuberculosis/Leprosy Control Unit. Manual of the National Tuberculosis/Leprosy Programme in Tanzania of the district tuberculosis/Leprosy Coordinators (2nd edition, 1987). Ministry of Health, P.O. Box 9083, Dar-es-Salaam.

7 Browne SG. Self-healing Leprosy: Report on 2749 patients. Lepr Rev, 1974; 45: 104-111.

8 Noordeen SK. Evolution of tuberculoid leprosy in a community. Leprosy in India, 1975; 47: 85-93.

9 Sirumban A, Kumar Ashok, Neelan PN. Healing time in untreated paucillary leprosy. A cross-sectional study. Int J Lep, 1988; 56: 223-227.

10 Pettit JHS. Should indeterminate leprosy ever be diaagnosed? (letter to the editor). Int J Lep, 1981; 49: 95-96.

" Pönnighaus JM, Fine PEM, Bliss L, Sliney IJ, Bradley DJ, Rees RJW. The Lepra Evaluation Project, an epidemiological study of leprosy in northern Malaŵi. I-Methods. Lepr Rev, 1987; 58: 359-375.

12 Fine PEM, Pönnighaus JM. Leprosy in Malaŵi 2. Background, design and prospects of the Karonga Prevention Trial, a leprosy vaccine trial in Northern Malaŵi. Trans Royal Soc Trop Med Hygiene, 1988; 82: 810-817.

13 Pönnighaus JM, Fine PEM, Bliss L. Certainty levels in the diagnosis of leprosy. Int J Le pr, 1987; 55: 454-462.

14 Pönnighaus JM, Fine PEM. A comparison of sensory loss tests and histopathology in the diagnosis of leprosy. Lepr Rev, 1989; 60: 20-27.

${ }^{15}$ Fine PEM, Job CK, McDougall AC, Meyers WM, Pönnighaus JM. Comparability among histopathologists in the diagnosis and classification of lesions suspected of leprosy in Malawi. Int J Lepr, 1986; 54: 614-625.

16 McDougall AC, Pönnighaus JM, Fine PEM. Histopathological examination of skin biopsies from an epidemiological study of leprosy in Northern Malawii. Int J Lepr, 1987; 55: 88-98.

17 Srinivasan H, Stumpe B. Value of thermal sensibility testing in leprosy diagnosis in the field-field trial of a pocket device. Lepr Rev, 1989; 60: 317-326.

18 Gupte MD, Valli Shayee RS, Nagaraju B, Ramalingam A, Lourdusamy G, Kannan. Inter-observer agreement and clinical diagnosis of leprosy for prophylaxis studies. Ind J Le pr, 1990; 62: 281-295. 


\title{
Surveillance active à long terme de suspects lépreux-que faut-il en attendre?
}

\author{
J. M. Pönnighaus, P. E. M. Fine, J. A. Sterne, S. B. Lucas et \\ A. C. MeDougall
}

Résumé Nous présentons les résultats dela suivie à long terme d e 277 suspects lépreux d u District de Karonga en Malaŵi du Nord qui ne recevaient pas de traitement contre la lèpre ou n'étaient pas sous surveillance active. Sont exclues de cette étude les personnes qui ont été mises sous traitement anti-lèpre moins d'un an après avoir été déclarées pour la première fois suspects de lèpre, habituellement sur la base d'examens histopathologiques; en effet, leur surveillance active ne devrait pas poser de problèmes d'organisation ou de financement dans les projets de contrôle de la lèpre. Après une période de suivie de 4,5 années en moyenne, nous avons diagnostiqué ce que nous considérons comme lèpre sans équivoque chez 35 des 277 suspects compris dans notre étude (13\%) et 3 de ces 35 suspects présentaient des infirmités. Chez 211 des $277(76 \%)$ tout signe de lèpre avait complètement disparu.

En comparant les certitudes cliniques au premier et dernier examen et en comparant les certitudes cliniques aux certitudes histopathologiques au dernier examen on estime que jusqu'à $50 \%$ des 35 cas de lèpre sans équivoque qui sont survenus dans ce groupe pouvaient être atribués à une erreur de diagnostic au ler ou 2ème examen plutôt qu'à une progression réelle de la maladie. Cette estimation est compatible avec une sensibilité globale de $90 \%$ et une spécificité globale de $95 \%$ à chaque examen. Les suspects de lèpre qui présentent 1 signe cardinal de lèpre, soit une lésion typique sans perte de sensation, soit une perte de sensation sur une lésion par ailleurs non typique, devraient être classés dans un groupe à haut risque, car, par la suite, nous avons observé $25 \%$ environ de cas de lèpre sans équivoque dans cette catégorie de suspects (19/78). Il faudrait formuler la conduite à tenir vis-à-vis de ces suspects dans les projets de contrôle de la lèpre.

\section{Vigilancia activa a largo plazo de posibles leprosos-:Qué posibilidad hay de que tenga éxito?}

\author{
J. M. Pönnighaus, P. E. M. Fine, J. A. Sterne, S. B. Lucas y \\ A. C. McDougall
}

Resumen El Distrito de Karonga en el Norte de Malaui presenta datos sobre el estudio posterior a largo plazo de 277 posibles leprosos que no recibieron tratamiento contra la lepra ni fueron activamente vigilados. Los individuos que comenzaron el tratamiento antilepra dentro de un año después de que se sospechase lepra, generalmente basado en los resultados histopatológicos, fueron excluidos de este análisis, porque una vigilancia activa normalmente no causaría un problema organizacional o financiero para los proyectos de control de la lepra. Después de un período de estudio posterior con un promedio de 4, 5 años, 35 de los 277 posibles leprosos incluidos en el análisis (13\%) fueron diagnosticados de leprosos inequívocos, y 3 de los 35 habián desarrollado incapacidades. En 211/277 (76\%), todas las indicaciones habían desaparecido totalmente.

Comparando las certezas clínicas en los primeros y últimos examenes, y comparando certezas clínicas con las histopatológicas, se calcula que hasta $50 \%$ de los 35 casos de lepra inequívoca que apareció en este grupo se debía a un diagnóstico equivocado en el ler. o 2o. examen, más bien que a un progreso verdadero de la enf ermedad. Este cálculo es compatible con una sensibilidad global del $90 \%$ y una especificidad global de $95 \%$ en cada examen. Los posibles leprosos con 1 indicación cardenal de la lepra, sea una lesión típica sin pérdida de sensación, sea con pérdida de sensación en el caso de una lesión que en otro caso sería atípica, deben ser considerados un grupo de riesgo elevado ya que aproximadamente un $25 \%$ de tales posibilidades (19/78) posteriormente presentaron lepra inequívoca. Los proyectos para el control de la lepra deberán formular políticas para el trato de tales posibles leprosos. 